\title{
Health Risk Factors And Health Care Systems In Latin America And The Caribbean: A Cross-Sectional Multiple Regression And ANOVA Analysis
}

Rina Samant, Ponte Vedra High School, Florida, USA

Sonia Samant, Ponte Vedra High School, Florida, USA

\begin{abstract}
The purpose of this research is to examine the effect of health risk factors and health care systems on child mortality and life expectancy in Latin America and the Caribbean (LAC). Cross-sectional multiple regression and Analysis of Variance (ANOVA) are used to study the association between health risk factors such as incidence of tuberculosis and diabetes, and health care systems such as number of hospital beds per capita, and number of physicians per capita on life expectancy and child mortality. Data are obtained from the World Bank. For the purpose of this study, the LAC region is defined as the area from Mexico to the southern end of South America, as well as islands in the Caribbean Sea and the Gulf of Mexico. The conclusions of the study are that higher life expectancy is associated with higher per capita incomes and health expenditures. On the other hand, higher child mortality is associated with greater prevalence of communicable diseases and poor maternal pre-natal conditions. The macro policy implication is to focus on economic development and health care expenditure. The micro policy implication is to allocate more resources for maternal care, preventive care and eradication of communicable diseases.
\end{abstract}

Keywords: Health Risk Factors; Health Care Systems; Latin America and the Caribbean; Life Expectancy; Child Mortality

\section{INTRODUCTION}

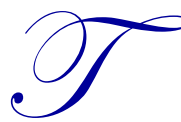

he LAC region is vast and covers a population of over 516 million in 2013. The region is very diverse in terms of level of economic development, income distribution and availability of health care. There are eighteen countries in the region for which data is available. The countries are Argentina, Barbados, Belize, Brazil, Chile, Colombia, Costa Rica, Ecuador, El Salvador, Guatemala, Guyana, Haiti, Honduras, Jamaica, Mexico, Peru, Vanuatu, and Venezuela. Although Vanuatu is located in the South Pacific, it is included in this study because of cultural affinity with several countries in the LAC región.

Tables are appended at the end of the text. Table 1 lists the countries included in the study. The two countries in the region with the largest populations are Brazil (196.7 million) and Mexico (114.8 million). The two smallest countries are Vanuatu ( 0.25 million) and Barbados ( 0.27 million). Life expectancy ranges from 79 years in Chile and Costa Rica to 62 years in Haiti. The mortality rate (per 1000 live births for children under age 5) ranges from a low of 9 in Chile to a high of 70 in Haiti. The percentage of population with access to improved water sources ranges from a high of 100 percent in Barbados to 69 percent in Haiti.

Table 2 reports data on gross national income and on income distribution in the Latin American and Caribbean region. The countries with the highest per capita national income measured in US Dollars at current prices are Barbados (USD 12,660) followed by Chile (USD 12, 280) and Venezuela (USD 11,920). The lowest per capita income is in Haiti (USD 700). The Gini Coefficient is a measure of income inequality in a country or region. 
Low figures indicate low income inequality. In a country where everyone earns an equal income, the Gini Coefficient would be 0 . Conversely, in a country where only one person earns all the income, the Gini coefficient would be 100. As shown in Table 2, the country with the least income inequality is Argentina (Gini Coefficient is 44), and the country with the greatest income inequality is Haiti (Gini Coefficient is 59). Another measure of income inequality is the difference in the proportion of national income earned by the the highest earning 20 percent and lowest earning 20 percent. This difference is the least in case of Argentina and most in case of Haiti. This result is consistent with the findings from the Gini Coefficient.

Table 3 shows health risk factors in the region. From among the countries who report data on the prevalence of smoking, the highest percentage of adults who smoke is in Chile. Regarding the incidence of TB, the disease is almost non-existent in Barbados (1 per 100,000 population), and is endemic in Haiti (222 per 100,000 population). The incidence of diabetes among adults of ages 20-79 is lowest in Argentina (5.6 percent) and highest in Vanuatu (22 percent).

Table 4 reports the prevalence of HIV in the region. The country with the highest percentage of adults between the ages of 20-49 infected with HIV is Belize (2.3 percent). From among people aged 15 years or older and infected with the HIV virus, the country with the highest percentage of women among HIV adults is in Haiti with 60 percent. Regarding the prevalence of HIV among youth ages 15-24, the country with the highest percentage of infected youth, both male and female, is Jamaica. antiretroviral therapy coverage for HIV patients is highest in Mexico (84 percent) and lowest in Honduras (41 percent).

Table 5 lists the causes of deaths in each country in the region. The first column reports the percentage of deaths that are attributed to communicable diseases, and maternal prenatal and nutrition conditions. The country with the highest percentage is Haiti, with 54 percent of deaths due to these preventable causes. Costa Rica, at 7 percent, is the country with the smallest percentage of deaths from communicable diseases. Consequently, the country with the highest percentage of deaths from non-communicable diseases is also Costa Rica. The countries with the highest percentage of deaths from injuries are Columbia and Venezuela with 21 percent of deaths in each country being the result of accidents.

Table 6 reports health expenditure as a percentage of Gross Domestic Product. The country with the highest percentage is Costa Rica at 10.9 percent and the country with the lowest percentage is Vanuatu at 4.1 percent. Regarding the share of public expenditure in total expenditure on health services, Vanuatu is at the top of the list with 87.9 percent and Ecuador is last with 41 percent. When stated in dollar terms the per capita annual expenditure is highest in Barbados at USD 1600, and is lowest in Haiti at a USD 58 per year.

\section{LITERATURE REVIEW}

An article by Fleury (1998) compares the effectiveness of health reforms in Argentina, Brazil, and Mexico by surveying patients about their experiences with the health care systems in each country. She found that the populations of these countries had benefitted from improved health care, but the benefits were unequally distributed.

A research paper by Firebaugh (1999) examines the "Empirics of World Income Inequality." After researching the trend of world income inequality, he found that global income inequality had not risen in the last two decades of the $20^{\text {th }}$ century, unlike the trend seen over the past two centuries. This finding was different from the conclusions of earlier studies which say that global income inequality continuously rose in the last two decades of the $20^{\text {th }}$ century. This difference happened because, in earlier studies, the data analysts had given equal weight to all countries irrespective of their populations when calculating income inequality. When the size of the population is used to weight the results, as was done in Firebaugh's study, there is no evidence in the data to show that global inequality is rising.

Income inequality is one of the explanatory variables in this study. The statistical measure most commonly used to calculate income equality is the "Gini Coefficient." A Gini Coefficient of 0 indicates that everyone in a particular country earns an equal income. The maximum value for a Gini Coefficient is 100. It means that a single person in a particular country earns all the income, while everyone else has no income. The Gini Coefficient is based 
on a measure of income inequality called a Lorenz Curve. A study by Wen-Chung Lee (1999) explained the information that was contained in the Lorenz Curve.

The availability of medical facilities in a country is linked to its level of income. Maceira (2006) performed a study on "Comparative Health Systems in Latin America: Organization, Results and Equities." He studied health systems in Latin America and examined their organization, results, and effects on equal availability of healthcare. His analysis was in two dimensions: the financial aspects of health care and the extent of government involvement in the health sector. Maceira found that infant mortality had declined in Latin America. He also examined the percentage of communicable and non-communicable disease in each country, the relation between per capita income and health care expenditure, as well as the relation between infant mortality rate and per capita health expenditure. He found that when public authorities were involved in health care, the benefits were more equitable. However, outof-pocket health expenditures were high, particularly in low income countries. Income inequalities created gaps in the health system. Also, peoples' ability to pay for health care affected their health.

Countries that keep better public health accounts tend to have better healthcare systems, as an article by Magnoli (2001) on "National Health Accounts in Latin America and Caribbean: Concepts, Results and Policy Uses," explains. This article focuses on the financial aspects of health reform, and talks about the importance of keeping accurate and up to date accounts on healthcare matters. In particular, Magnoli discussed the national health accounts, how they are used, and how they can be implemented in the LAC region, as well as the challenges and drawbacks of using these accounts. Nations with better health accounts had more information to use in case of unforeseen events such as epidemics, and also had more information to make decisions on how to allocate scarce resources.

A report published by the Inter-American Development Bank (1998) studied the water supply in Argentina. This report found that when the provision of water was done by private companies, the distribution was more efficient. This report also said that the supply of water should be carefully monitored for quality. The availability of clean, non-polluted water is very important for maintaining the health of the country. It reduces the level of diseases that are transmitted through the water supply.

A report on non-communicable diseases by the Inter-American Development Bank (2012) was published on Latin America. Its title was "Support for Prevention and Control of NCDs". In countries with higher levels of per capita income, non-communicable diseases, such as diabetes and heart disease, are more common causes of death than communicable diseases, such as tuberculosis. This report studied the Latin American country of Suriname. In the country, the most common causes of death were cardiovascular disease, diabetes, and cancer. Given the high rate of cardiovascular disease, this report studied the food industry in the country. It showed that it is important to control the ingredients that go into making processed foods. The report also stated that there should be public/private partnerships in the area of primary health in order to manage the challenges that the health system was facing in the country.

A paper on "Global Burden of Disease: Generating Evidence, Guiding Policy-Latin America and Caribbean Regional Edition" was published by the Institute for Health Metrics and Evaluation in 2010. This paper compared figures on diseases and injuries in Latin America and the Caribbean with other regions of the world. It examined the role of chronic diseases, violence, and road traffic injuries. It explored the main causes of premature deaths and disability in Latin America. It examined the role of poor diet, high blood pressure, and alcohol abuses in the region. It estimated the utilization of inpatient and outpatient health services. The study found that in the Latin America and Caribbean (LAC) region, non-communicable diseases were a leading cause of mortality, as communicable diseases, and maternal and nutritional health issues were declining. However, HIV/AIDS was on the rise. Violence and road injuries were also a leading cause of death. Illnesses relating to children remained at high levels in Bolivia and Haiti. The study found that between 1970 and 2010, the average age of death rose by more than 30 years in many countries in the region. Likewise, infant mortality has fallen significantly, but there is still scope for lowering the rates further.

Data on life expectancy, infant mortality, and socioeconomic variables are available in two online publications, the World Bank Global Atlas of Development 2013, and the World Bank World Development 
Indicators 2013. Both these publications are available on the website of the World Bank. The World Bank publishes this data free of cost as a service for researchers all over the world. In addition, all the data on national income and health expenditures for all the countries in the World Bank reports are in US dollars so that cross-country comparisons can be made without conversion into a common currency using multiple exchange rates.

\section{METHODOLOGY}

The data were used to run several multiple regression equations. In each equation, the response variable is either life expectancy or child mortality rate. The explanatory variables differ in each equation. The set of explanatory variables includes the socio-economic variables of per capita gross national income, income inequality, health expenditure per capita, physicians per capita, and health variables limited to incidence of tuberculosis, diabetes, and HIV/Aids. Within each equation, t-tests are used to verify whether individual regression coefficients are statistically significant. Also, for each equation, Analysis of Variance (ANOVA) procedure is used to construct an F-statistic to verify whether the explanatory variables taken together are able to explain the variation in the response variable to an extent that is statistically significant. Based on the results of the t-test and the F-test, inferences are made on the ability of each socio-economic variable or health variable to explain the variation in life expectancy and infant mortality in the LAC region.

\section{RESULTS}

The following cross-sectional linear multiple regressions were run:

\section{Equation 1}

$$
Y_{1 i}=\alpha_{1}+\beta_{11} X_{11 i}+\beta_{12} X_{12 i}+\varepsilon_{1 i}
$$

where $\quad Y_{1 i}=$ Life expectancy at birth for country “i”"

$\mathrm{X}_{11 \mathrm{i}}=$ Gross National Income (GNI) per capita for country "i”"

$\mathrm{X}_{12 \mathrm{i}}=$ Gini Coefficient for Income Inequality in country “i”"

$\varepsilon_{1 \mathrm{i}}=$ Random error term

The results of the multiple regressions are as follows:

\begin{tabular}{|c|c|c|c|c|c|c|}
\hline \multicolumn{7}{|c|}{ Regression Statistics } \\
\hline Multiple R & 0.658515062 & & \multicolumn{2}{|c|}{ Adjusted R Square } & \multicolumn{2}{|l|}{0.346510101} \\
\hline R Square & 0.433642087 & & \multicolumn{2}{|c|}{ Standard Error } & 3.246574733 & \\
\hline Observations & 16 & & & & & \\
\hline \multicolumn{7}{|c|}{ ANOVA } \\
\hline & Df & SS & MS & $\mathbf{F}$ & Significance $\mathbf{F}$ & \\
\hline Regression & 2 & 104.9142825 & 52.45714 & 4.976842 & 0.024836553 & \\
\hline Residual & 13 & 137.0232175 & 10.54025 & & & \\
\hline Total & 15 & 241.9375 & & & & \\
\hline & Coefficients & Standard Error & t Stat & P-value & Lower 95\% & Upper 95\% \\
\hline Intercept & 76.94130888 & 10.09199901 & 7.623991 & $3.77 \mathrm{E}-06$ & 55.13887054 & 98.74375 \\
\hline $\mathrm{X}_{11}$ & 0.000626823 & 0.000244451 & 2.56421 & 0.023551 & $9.87193 \mathrm{E}-05$ & 0.001155 \\
\hline$X_{12}$ & -0.14232669 & 0.185700416 & -0.76643 & 0.457112 & -0.54350804 & 0.258855 \\
\hline
\end{tabular}

\section{Test Diagnostics}

Given the relatively low value of the adjusted $\mathrm{R}^{2}$ above, it is evident that only about 35 percent of the variation in life expectancy can be explained by differences in per capita GNI and income inequality. However, the F statistic is significant, at 0.0248 level, suggesting that the association between life expectancy, per capita GNI, and income inequality is not purely random. The t-statistic associated with the coefficient of per capita GNI is significant. Therefore the data suggest that changes in life expectancy in the Latin American and Caribbean region are positively correlated with changes in per capita GNI. 


\section{Equation 2}

$$
Y_{1 i}=\alpha_{2}+\beta_{21} X_{21 i}+\beta_{22} X_{22 i}+\varepsilon_{2 i}
$$

where $\quad Y_{1 i}=$ Life expectancy at birth for country " $i$ "

$\mathrm{X}_{21 \mathrm{i}}=$ Incidence of Tuberculosis for country "i"

$\mathrm{X}_{22 \mathrm{i}}=$ Incidence of Diabetes for country " $\mathrm{i}$ "

$\varepsilon_{2 \mathrm{i}}=$ Random error term

The results of the multiple regressions are as follows:

\begin{tabular}{|c|c|c|c|c|c|c|}
\hline \multicolumn{7}{|c|}{ Regression Statistics } \\
\hline Multiple R & 0.84026939 & & \multicolumn{2}{|c|}{ Adjusted R Square } & \multicolumn{2}{|l|}{0.666859668} \\
\hline R Square & 0.706052648 & & \multicolumn{2}{|c|}{ Standard Error } & \multirow{2}{*}{\multicolumn{2}{|c|}{2.258435498}} \\
\hline Observations & 18 & & & & & \\
\hline \multicolumn{7}{|c|}{ ANOVA } \\
\hline & df & SS & MS & $\mathbf{F}$ & Significance F & \\
\hline Regression & 2 & 183.7698143 & 91.88490715 & 18.014773 & 0.000102807 & \\
\hline Residual & 15 & 76.50796347 & 5.100530898 & & & \\
\hline Total & 17 & 260.2777778 & & & & \\
\hline & Coefficients & Standard Error & t Stat & P-value & Lower 95\% & Upper 95\% \\
\hline Intercept & 77.35750836 & 1.661803256 & 46.55034106 & $1.223 \mathrm{E}-17$ & 73.81545856 & 80.89956 \\
\hline$X_{21}$ & -0.06387423 & 0.010682578 & -5.979290514 & $2.525 \mathrm{E}-05$ & -0.08664361 & -0.0411 \\
\hline$X_{22}$ & -0.04107553 & 0.127747461 & -0.32153694 & 0.7522405 & -0.313362795 & 0.231212 \\
\hline
\end{tabular}

\section{Test Diagnostics}

The value of adjusted $\mathrm{R}^{2}$ is fairly high indicating that as much as 66 percent of the variation in life expectancy at birth is associated with the degree of prevalence of tuberculosis and diabetes. Also, the $\mathrm{F}$ statistic is highly significant in confirming the above. For the tuberculosis variable, the coefficient is negative and the t-test is significant, indicating that there is strong association between the incidence of high tuberculosis and low life expectancy.

\section{Equation 3}

$$
Y_{1 i}=\alpha_{3}+\beta_{31} X_{31 i}+\beta_{32} X_{32 i}+\varepsilon_{3 i}
$$

where $\quad Y_{1 i}=$ Life expectancy at birth for country “i”"

$\mathrm{X}_{3 \mathrm{i}}=$ Percentage of deaths due to communicable diseases for country " $\mathrm{i}$ "

$\mathrm{X}_{32 \mathrm{i}}=$ Percentage of deaths due to non-communicable diseases for country "i"

$\varepsilon_{3 \mathrm{i}}=$ Random error term

\begin{tabular}{|c|c|c|c|c|c|c|}
\hline \multicolumn{7}{|c|}{ Regression Statistics } \\
\hline Multiple R & 0.861126176 & & \multicolumn{2}{|c|}{ Adjusted R Square } & \multicolumn{2}{|l|}{0.70707673} \\
\hline R Square & 0.741538291 & & \multicolumn{2}{|c|}{ Standard Error } & \multicolumn{2}{|l|}{2.117732109} \\
\hline Observations & 18 & & & & & \\
\hline \multicolumn{7}{|c|}{ ANOVA } \\
\hline & df & SS & MS & $\mathbf{F}$ & Significance $\mathbf{F}$ & \\
\hline Regression & 2 & 193.0059 & 96.50297 & 21.51784 & $3.91716 \mathrm{E}-05$ & \\
\hline Residual & 15 & 67.27184 & 4.484789 & & & \\
\hline Total & 17 & 260.2778 & & & & \\
\hline & Coefficients & Standard Error & t Stat & P-value & Lower 95\% & Upper 95\% \\
\hline Intercept & 72.36527031 & 8.51395 & 8.499612 & $4.05 \mathrm{E}-07$ & 54.2182157 & 90.51232 \\
\hline$X_{31}$ & -0.22549694 & 0.100106 & -2.25258 & 0.039691 & -0.43886766 & -0.01213 \\
\hline$X_{32}$ & 0.0847588 & 0.098005 & 0.864841 & 0.400746 & -0.124133953 & 0.293652 \\
\hline
\end{tabular}

The results of the multiple regressions are as follows: 


\section{Test Diagnostics}

From the results above, the value of adjusted $\mathrm{R}^{2}$ is 0.707 indicating that almost 71 percent of the variance in life expectancy is associated with variance in the explanatory variables. The F statistic is highly significant, confirming that the explanatory variables are able to account for a significant proportion of the variation in life expectancy. The coefficient of the percentage of deaths due to communicable diseases is negative and the $t$ statistic associated with is statistically significant at the 3.9 percent level confirming that low life expectancy is associated with high percentage of deaths due to communicable diseases.

\section{Equation 4}

$$
Y_{2 i}=\alpha_{4}+\beta_{41} X_{41 i}+\beta_{42} X_{42 i}+\varepsilon_{4 i}
$$

where $\quad Y_{2 \mathrm{i}}=$ Mortality rate for children under the age of 5 for country " $\mathrm{i}$ "

$\mathrm{X}_{41 \mathrm{i}}=$ Percentage of population with access to purified drinking water for country " $\mathrm{i}$ "

$\mathrm{X}_{42 \mathrm{i}}=$ Percentage of deaths due to communicable diseases and maternal pre-natal conditions for country "i"

$\varepsilon_{5 \mathrm{i}}=$ Random error term

The results of the multiple regressions are as follows:

\begin{tabular}{|c|c|c|c|c|c|c|}
\hline \multicolumn{7}{|c|}{ Regression Statistics } \\
\hline Multiple R & 0.853682031 & & \multirow{2}{*}{\multicolumn{2}{|c|}{$\begin{array}{l}\text { Adjusted R Square } \\
\text { Standard Error }\end{array}$}} & \multicolumn{2}{|l|}{0.687045781} \\
\hline R Square & 0.72877301 & & & & 8.116777626 & \\
\hline Observations & 16 & & & & & \\
\hline \multicolumn{7}{|c|}{ ANOVA } \\
\hline & Df & SS & MS & $\mathbf{F}$ & Significance F & \\
\hline Regression & 2 & 2301.282973 & 1150.641 & 17.46517 & 0.000207331 & \\
\hline Residual & 13 & 856.4670273 & 65.88208 & & & \\
\hline \multirow[t]{2}{*}{ Total } & 15 & 3157.75 & & & & \\
\hline & Coefficients & Standard Error & t Stat & P-value & Lower 95\% & Upper 95\% \\
\hline Intercept & 23.1806256 & 55.09702736 & 0.420724 & 0.680829 & -95.84926538 & 142.21052 \\
\hline$X_{41}$ & -0.230095822 & 0.532115462 & -0.43242 & 0.672525 & -1.379661388 & 0.9194697 \\
\hline$X_{42}$ & 0.949463333 & 0.343383618 & 2.765022 & 0.01607 & 0.207628129 & 1.6912985 \\
\hline
\end{tabular}

\section{Test Diagnostics}

The value of adjusted $\mathrm{R}^{2}$ is 0.687 indicating that almost 69 percent of the variation in the child mortality rate is associated with variance in the explanatory variables. The $\mathrm{F}$ statistic is highly significant, confirming this result. The coefficient of the percentage of population with access to purified drinking water is negative. However, the $t$ statistic associated with this explanatory variable is not statistically significant. Finally, the t-statistic for the percentage of deaths due to communicable diseases is statistically significant, confirming that the association between the prevalence of communicable diseases and high incidence of child mortality is positive.

\section{Equation 5}

$$
Y_{2 i}=\alpha_{5}+\beta_{51} X_{51 i}+\beta_{52} X_{52 i}+\varepsilon_{5 i}
$$

where $\quad Y_{2 \mathrm{i}}=$ Mortality rate for children under the age of 5 for country " $\mathrm{i}$ "

$\mathrm{X}_{51 \mathrm{i}}=$ Percentage of population with HIV in age group 15-49 for country "i"

$\mathrm{X}_{52 \mathrm{i}}=$ Women's share of population with HIV in age group 15-49 for country "i'"

$\mathrm{E}_{5 \mathrm{i}}=$ Random error term 
The results of the multiple regressions are as follows:

\begin{tabular}{|c|c|c|c|c|c|c|}
\hline \multicolumn{7}{|c|}{ Regression Statistics } \\
\hline Multiple R & 0.629575 & & \multicolumn{2}{|c|}{ Adjusted R Square } & \multicolumn{2}{|l|}{0.295759} \\
\hline R Square & 0.396365 & & \multicolumn{2}{|c|}{ Standard Error } & \multicolumn{2}{|l|}{12.65428} \\
\hline Observations & 15 & & & & & \\
\hline \multicolumn{7}{|c|}{ ANOVA } \\
\hline & df & SS & MS & $\mathbf{F}$ & Significance F & \\
\hline Regression & 2 & 1261.763 & 630.8813 & 3.93978487 & 0.048377742 & \\
\hline Residual & 12 & 1921.571 & 160.1309 & & & \\
\hline Total & 14 & 3183.333 & & & & \\
\hline & Coefficients & Standard Error & t Stat & P-value & Lower $95 \%$ & Upper 95\% \\
\hline Intercept & -1.3424 & 9.336009 & -0.14379 & 0.88805522 & -21.68381213 & 18.99902 \\
\hline $\mathrm{X}_{51}$ & 6.63838 & 5.793526 & 1.145827 & 0.27420346 & -5.984630023 & 19.26139 \\
\hline$X_{52}$ & 0.506332 & 0.276691 & 1.829956 & 0.09219458 & -0.096525591 & 1.109189 \\
\hline
\end{tabular}

\section{Test Diagnostics}

The value of adjusted $\mathrm{R}^{2}$ is 0.296 indicating that about 30 percent of the variation in the children under 5 mortality rate can be explained by the independent variables. The $\mathrm{F}$ statistic is significant at $5 \%$ level, indicating that the variation in child mortality rate is associated with variance in the percentage of population with HIV/Aids and women's share of population with HIV. Neither of the t-statistics associated with the explanatory variables is significant at 5 percent level.

\section{Equation 6}

$$
Y_{1 i}=\alpha_{6}+\beta_{61} X_{61 i}+\beta_{62} X_{62 i}+\beta_{63} X_{63 i}+\beta_{64} X_{64 i}+\varepsilon_{6 i}
$$

where $\mathrm{Y}_{1 \mathrm{i}}=$ Life expectancy at birth for country " $\mathrm{i}$ "

$\mathrm{X}_{61 \mathrm{i}}=$ Per capita health expenditure (in US Dollars) in country “i”

$\mathrm{X}_{62 \mathrm{i}}=$ Number of Physicians per 1000 people in country "i"

$X_{63 i}=$ Number of Nurses and Midwives per 1000 people in country "i"

$\mathrm{X}_{64 \mathrm{i}}=$ Number of Hospital beds per 1000 people in country "i"

$\varepsilon_{6 \mathrm{i}}=$ Random error term

The results of the multiple regressions are as follows:

\begin{tabular}{|c|c|c|c|c|c|c|}
\hline \multicolumn{7}{|c|}{$\begin{array}{l}\text { Regression Statistics } \\
\end{array}$} \\
\hline Multiple R & 0.81075854 & & \multicolumn{2}{|c|}{$\begin{array}{l}\text { Adjusted R Square } \\
\text { Standard Error }\end{array}$} & \multicolumn{2}{|l|}{0.42888235} \\
\hline \multirow{2}{*}{\multicolumn{7}{|c|}{ Adjusted R }} \\
\hline & & & & & & \\
\hline Square & 0.42888235 & & & & & \\
\hline Standard Error & 2.01239741 & & & & & \\
\hline Observations & 11 & & & & & \\
\hline \multicolumn{7}{|c|}{ ANOVA } \\
\hline & df & SS & MS & $\mathbf{F}$ & Significance $\mathbf{F}$ & \\
\hline Regression & 4 & 46.610631 & 11.65265775 & 2.877381808 & 0.119585239 & \\
\hline Residual & 6 & 24.29845991 & 4.049743318 & & & \\
\hline Total & 10 & 70.90909091 & & & & \\
\hline & Coefficients & Standard Error & t Stat & P-value & Lower 95\% & Upper 95\% \\
\hline Intercept & 72.066505 & 1.225212544 & 58.81959453 & $1.62254 \mathrm{E}-09$ & 69.06851793 & 75.06449212 \\
\hline $\mathrm{X}_{61}$ & 0.00616684 & 0.002530745 & 2.436768649 & 0.050693819 & $-2.567 \mathrm{E}-05$ & 0.012359349 \\
\hline$X_{62}$ & 0.92811833 & 1.233855495 & 0.752209911 & 0.480382712 & -2.0910173 & 3.947253964 \\
\hline$X_{63}$ & -0.78657617 & 0.46160397 & -1.704006514 & 0.13926715 & -1.9160804 & 0.342928053 \\
\hline$X_{64}$ & -0.46385268 & 0.690900036 & -0.671374519 & 0.526970046 & -2.15442417 & 1.226718807 \\
\hline
\end{tabular}




\section{Test Diagnostics}

The value of adjusted $R^{2}$ is 0.428 indicating that about 43 percent of the variation in the life expectancy rate can be attributed to variation in the explanatory variables. The F statistic is not significant at 5 percent level. The coefficient of per capita health expenditure is positive and significant at 5 percent level. Thus there is some evidence in the data of positive association between higher per capita health expenditure and longer life expectancy.

\section{DISCUSSION}

The Latin America and Caribbean region is very diverse in terms of income levels, income inequality, access to health care, availability of physicians, nurses, hospital beds, and prevalence of communicable and noncommunicable diseases. For countries in the LAC region, Equation 1 suggests that longer life expectancy is related to higher per capita income levels. Equation 2 indicates that longer life expectancy is associated with low prevalence of tuberculosis. There was no evidence to link life expectancy with prevalence of diabetes. Equation 3 suggests that shorter life expectancy is related to greater prevalence of communicable diseases. Equation 4 indicates that, as expected, the rate of child mortality is associated with prevalence of maternal pre-natal conditions and communicable diseases. Equation 5 suggests that the variability in child mortality rate is associated with variance in the percentage of population with HIV/Aids as well as women's share of population with HIV. Finally, as shown in Equation 6, there was no evidence in the data to link life expectancy with the number of physicians, nurses or hospital beds. However, the data do suggest that greater health expenditure per capita is associated with higher life expectancy. Perhaps, greater health expenditures lead to greater preventive care as opposed to cure of sickness and disease.

The results need to be interpreted with caution. In some countries, particularly those with higher per capita incomes, the leading cause of death is non-communicable disease such as diabetes, while in countries with lower per capita income levels, the leading cause of death is communicable disease such as tuberculosis. This study does not make a distinction between these two groups of countries. Further, there are gender differences in child mortality rates and in life expectancy which are not analyzed in this study.

\section{CONCLUSION}

This research examines data from Latin American and Caribbean countries in order to investigate the relationship between socio-economic factors, health risk factors and life expectancy and child mortality rates. Socioeconomic factors include income levels and health care expenditure. Health risk factors include the prevalence of HIV/AIDS, and diseases such as tuberculosis and diabetes. Higher life expectancy is associated with higher per capita incomes and health expenditures. On the other hand, higher child mortality is associated with greater prevalence of communicable diseases and poor maternal pre-natal conditions. The policy implication at macro level is to focus on economic development and raising health expenditures and at micro level to allocate more resources for maternal care, preventive care and eradication of communicable diseases.

In follow-up studies, the eighteen countries examined in this research could be split into two groups. The first group would include countries in which the leading causes of death are communicable diseases such as tuberculosis. Haiti would be a country in this group. The other group would be the nations that can attribute most of their deaths to non-communicable diseases such as diabetes. Argentina and Barbados are two countries that would be included in this group. Statistical analyses can then be carried out for each group individually to determine the effects of health risk factors and health care systems on these countries. Such further research could help refine health policies in all of these countries.

\section{AUTHOR INFORMATION}

Rina Samant is a senior at Ponte Vedra High School, 460 Davis Park Road, Ponte Vedra, Florida 32081 USA. Her research interests lie in the areas of human medicine, disease prevention and medical services for underserved communities. She can be contacted at Email: risam88@ gmail.com 
Sonia Samant is a senior at Ponte Vedra High School, 460 Davis Park Road, Ponte Vedra, Florida 32081 USA. Her research interests lie in the areas of medicine, disease control and health care systems. Her contact email for academic research is as above.

\section{ACKNOWLEDGEMENTS}

This research was presented at the Clute Institute International Academic Conference, Lake Buena Vista, FL, 2-4 January 2014. The authors would like to thank session participants for their comments. In particular, the authors would like to thank Dr. Ronald Clute for his suggestions, which have been incorporated in this paper. The authors would also like to thank Mr. Steve Lyons, Dr. Karen Ford, Mr. Dustin Latta, and Dr. Ajay Samant for their comments on earlier drafts. Any errors or inaccuracies that may remain in the text are the responsibility of the authors only.

\section{REFERENCES}

1. Firebaugh, Glenn, (1999) "Empirics of World Income Inequality", American Journal of Sociology, 104 (6): $1597-1630$

2. $\quad$ Fleury, Sonia, (1998) "Reshaping Latin American Health Care Systems: Towards Fairness", InterAmerican Development Bank.

3. Inter-American Development Bank, (1998) Strengthening of Provincial Regulatory Agencies and Support for Privatization of the Water Supply and Sanitation Sector (Project Number TC-98-06-32-6).

4. Inter-American Development Bank, (2012) Support for Prevention and Control of NCDs (Project Number SU-T1062).

5. Institute for Health Metrics and Evaluation, (2010) Global Burden of disease: Generating Evidence, Guiding Policy-Latin America and Caribbean Regional Edition.

6. Maceira, Daniel, (2006) "Comparative Health Systems in Latin America: Organization, Results and Equities", Centro de Estudios de Estado Y Sociedad (CEDES).

7. Magnoli, Alessandro, (2001) "National Health Accounts in Latin America and Caribbean: Concepts, Results and Policy Uses", Inter-American Development Bank.

8. Wen-Chung, Lee, (1999) "Probabilistic Analysis of Global Performance of Diagnostic tests: Interpreting the Lorenz Curve based Summary Measures", Statistics in Medicine, 18(4): 455-471.

9. World Bank, (2013) Atlas of Global Development Fourth Edition.

10. World Bank, (2013) World Development Indicators. 


\section{APPENDIX}

Table 1

\begin{tabular}{lcccc}
\hline \multicolumn{1}{c}{ Country } & Population (Millions) & $\begin{array}{c}\text { Life Expectancy At } \\
\text { Birth (Years) }\end{array}$ & $\begin{array}{c}\text { Under 5 Mortality } \\
\text { Rate Per 1000 Live } \\
\text { Births }\end{array}$ & $\begin{array}{c}\text { Access To Improved } \\
\text { Water Source }\end{array}$ \\
\hline Argentina & 40.76 & 76 & 14 & NA \\
Barbados & 0.27 & 77 & 20 & 100 \\
Belize & 0.36 & 76 & 17 & 98 \\
Brazil & 196.66 & 73 & 16 & 98 \\
Chile & 17.27 & 79 & 9 & 96 \\
Colombia & 46.93 & 73 & 18 & 92 \\
Costa Rica & 4.73 & 79 & 10 & 97 \\
Ecuador & 14.67 & 75 & 23 & 94 \\
El Salvador & 6.23 & 72 & 15 & 88 \\
Guatemala & 14.76 & 71 & 30 & 92 \\
Guyana & 0.76 & 70 & 36 & 94 \\
Haiti & 10.12 & 62 & 21 & 69 \\
Honduras & 7.75 & 73 & 18 & 87 \\
Jamaica & 2.71 & 73 & 16 & 93 \\
Mexico & 114.79 & 77 & 18 & 96 \\
Peru & 29.4 & 74 & 13 & 85 \\
Vanuatu & 0.25 & 71 & 15 & 90 \\
Venezuela & 29.28 & 74 & & NA \\
\hline Data reported in all the tables are from & & & & \\
2013. & & & & \\
\hline
\end{tabular}

Table 2

\begin{tabular}{|c|c|c|c|c|}
\hline \multirow[b]{2}{*}{ Country } & \multirow{2}{*}{$\begin{array}{c}\text { Gross National } \\
\text { Income Per Capita } \\
\text { (US Dollars) }\end{array}$} & \multicolumn{3}{|c|}{ Percent Share of Income } \\
\hline & & Gini Coefficient & $\begin{array}{c}\text { Highest } \\
20 \%\end{array}$ & $\begin{array}{c}\text { Lowest } \\
20 \%\end{array}$ \\
\hline Argentina & 9,740 & 44 & 49 & 5 \\
\hline Barbados & 12,660 & NA & NA & NA \\
\hline Belize & 3,690 & 53 & 58 & 3 \\
\hline Brazil & 10,720 & 55 & 59 & 3 \\
\hline Chile & 12,280 & 52 & 58 & 4 \\
\hline Colombia & 6,110 & 56 & 60 & 3 \\
\hline Costa Rica & 7,660 & 51 & 56 & 4 \\
\hline Ecuador & 4,140 & 49 & 54 & 4 \\
\hline El Salvador & 3,480 & 48 & 53 & 4 \\
\hline Guatemala & 2,870 & 56 & 60 & 3 \\
\hline Guyana & 2,900 & 45 & 50 & 4 \\
\hline Haiti & 700 & 59 & 63 & 2 \\
\hline Honduras & 1,970 & 57 & 60 & 2 \\
\hline Jamaica & 4,980 & 46 & 52 & 2 \\
\hline Mexico & 9,240 & 47 & 53 & 5 \\
\hline Peru & 5,500 & 48 & 53 & 4 \\
\hline Vanuatu & 2,870 & NA & NA & NA \\
\hline Venezuela & 11,920 & 45 & 49 & 4 \\
\hline
\end{tabular}


Table 3

\begin{tabular}{lcccc}
\hline \multicolumn{1}{c}{ Country } & \multicolumn{2}{c}{ Health Risk Factors } \\
\hline & \multicolumn{2}{c}{$\begin{array}{c}\text { Prevalence Of Smoking } \\
\text { \% Of Adults }\end{array}$} & $\begin{array}{c}\text { Incidence Of TB } \\
\text { Per 100,000 People }\end{array}$ & $\begin{array}{c}\text { Prevalence Of } \\
\text { Diabetes: \% Of } \\
\text { Population Ages 20-79 }\end{array}$ \\
\hline Argentina & Male & Female & & 5.6 \\
Barbados & 32 & 22 & 26 & 12.4 \\
Belize & 13 & 1 & 1 & 16 \\
Brazil & 23 & 3 & 40 & 10.5 \\
Chile & 22 & 13 & 42 & 12.8 \\
Colombia & 38 & 33 & 18 & 7.3 \\
Costa Rica & NA & NA & 34 & 8.8 \\
Ecuador & 24 & 8 & 12 & 6.9 \\
El Salvador & NA & NA & 62 & 9.9 \\
Guatemala & NA & NA & 27 & 9.9 \\
Guyana & 22 & 4 & 61 & 16.1 \\
Haiti & 27 & 6 & 110 & 6.7 \\
Honduras & NA & NA & 222 & 7.1 \\
Jamaica & NA & 3 & 43 & 12.3 \\
Mexico & NA & NA & 7 & 15.6 \\
Peru & 24 & 8 & 23 & 6.8 \\
Vanuatu & NA & 9 & 101 & 22 \\
Venezuela & 43 & 8 & 67 & 10.4 \\
\hline
\end{tabular}

Table 4

\begin{tabular}{|c|c|c|c|c|c|}
\hline \multirow[b]{2}{*}{ Country } & \multicolumn{4}{|c|}{ Prevalence Of HIV } & \multirow[b]{2}{*}{$\begin{array}{c}\text { Antiretroviral } \\
\text { Therapy Coverage } \\
\% \text { Of People With } \\
\text { Advanced HIV } \\
\text { Infection } \\
\end{array}$} \\
\hline & $\begin{array}{l}\text { Total \% Of } \\
\text { Population } \\
\text { Ages 15-49 }\end{array}$ & $\begin{array}{l}\text { Women's Share } \\
\text { Of Population } \\
\text { With HIV } \\
\text { Ages 15+ }\end{array}$ & $\begin{array}{c}\text { Male Youth \% } \\
\text { Of Population } \\
\text { With HIV } \\
\text { Ages 15-24 }\end{array}$ & $\begin{array}{c}\text { Female Youth \% } \\
\text { Of Population } \\
\text { With HIV } \\
\text { Ages 15-24 }\end{array}$ & \\
\hline Argentina & 0.4 & 39 & 0.2 & 0.2 & 79 \\
\hline Barbados & 0.9 & NA & 0.3 & 0.3 & NA \\
\hline Belize & 2.3 & 41 & 1 & 1 & 62 \\
\hline Brazil & 0.3 & 42 & 0.1 & 0.1 & 71 \\
\hline Chile & 0.5 & 9 & 0.3 & 0.1 & 66 \\
\hline Colombia & 0.5 & 20 & 0.4 & 0.1 & 46 \\
\hline Costa Rica & 0.3 & 50 & 0.1 & 0.2 & 73 \\
\hline Ecuador & 0.4 & 25 & 0.3 & 0.1 & 68 \\
\hline El Salvador & 0.6 & 42 & 0.3 & 0.3 & 72 \\
\hline Guatemala & 0.8 & 42 & 0.4 & 0.5 & 56 \\
\hline Guyana & 1.1 & 45 & 0.2 & 0.3 & 82 \\
\hline Haiti & 1.8 & 60 & 0.4 & 1.1 & 58 \\
\hline Honduras & NA & 36 & NA & NA & 41 \\
\hline Jamaica & 1.8 & 35 & 0.9 & 0.6 & 60 \\
\hline Mexico & 0.3 & 18 & 0.1 & 0.1 & 84 \\
\hline Peru & 0.4 & 29 & 0.2 & 0.1 & 60 \\
\hline Vanuatu & NA & NA & NA & NA & NA \\
\hline Venezuela & 0.6 & 26 & 0.4 & 0.1 & 79 \\
\hline
\end{tabular}


Table 5

\begin{tabular}{lccc}
\hline & & Cause Of Death (Percentages) & \\
\hline \multicolumn{1}{c}{ Country } & $\begin{array}{c}\text { Communicable Diseases } \\
\text { And Maternal Prenatal } \\
\text { \& Nutrition Conditions }\end{array}$ & $\begin{array}{c}\text { Non-Communicable } \\
\text { Diseases }\end{array}$ & Injuries \\
\hline Argentina & 14 & 80 & 6 \\
Barbados & 14 & 82 & 4 \\
Belize & 20 & 62 & 17 \\
Brazil & 14 & 74 & 12 \\
Chile & 9 & 83 & 8 \\
Colombia & 13 & 66 & 21 \\
Costa Rica & 7 & 81 & 13 \\
Ecuador & 20 & 65 & 15 \\
El Salvador & 17 & 67 & 16 \\
Guatemala & 35 & 47 & 18 \\
Guyana & 21 & 66 & 13 \\
Haiti & 54 & 41 & 5 \\
Honduras & 23 & 69 & 8 \\
Jamaica & 21 & 68 & 11 \\
Mexico & 12 & 78 & 10 \\
Peru & 30 & 60 & 10 \\
Vanuatu & 24 & 70 & 5 \\
Venezuela & 13 & 66 & 21 \\
\hline
\end{tabular}

Table 6

\begin{tabular}{|c|c|c|c|}
\hline \multirow[b]{2}{*}{ Country } & \multicolumn{3}{|c|}{ Health Expenditure } \\
\hline & $\begin{array}{c}\text { Total } \\
\% \text { of GDP }\end{array}$ & $\begin{array}{c}\text { Public } \\
\% \text { of Total }\end{array}$ & $\begin{array}{c}\text { Per Capita } \\
\text { Dollars }\end{array}$ \\
\hline Argentina & 8.1 & 60.6 & 1,434 \\
\hline Barbados & 7.7 & 64 & 1,600 \\
\hline Belize & 5.7 & 66.5 & 426 \\
\hline Brazil & 8.9 & 45.7 & 1,121 \\
\hline Chile & 7.5 & 47 & 1,075 \\
\hline Colombia & 6.1 & 74.8 & 432 \\
\hline Costa Rica & 10.9 & 70.1 & 943 \\
\hline Ecuador & 7.3 & 41 & 332 \\
\hline El Salvador & 6.8 & 63.3 & 251 \\
\hline Guatemala & 6.7 & 35.5 & 214 \\
\hline Guyana & 5.9 & 79.1 & 200 \\
\hline Haiti & 7.9 & 43.7 & 58 \\
\hline Honduras & 8.6 & 48.1 & 193 \\
\hline Jamaica & 4.9 & 54.1 & 270 \\
\hline Mexico & 6.2 & 49.4 & 620 \\
\hline Peru & 4.8 & 56.1 & 289 \\
\hline Vanuatu & 4.1 & 87.9 & 134 \\
\hline Venezuela & 5.2 & 36.7 & 555 \\
\hline
\end{tabular}

